\title{
Large-scale testing of a sandwich shaft-sealing system at the Mont Terri rock laboratory
}

\author{
Klaus Wieczorek ${ }^{1}$, Katja Emmerich ${ }^{2}$, Rainer Schuhmann ${ }^{2}$, Jürgen Hesser ${ }^{3}$, Markus Furche ${ }^{3}$, \\ David Jaeggi $^{4}$, Senecio Schefer ${ }^{4}$, Jan Aurich ${ }^{5}$, Juan Carlos Mayor ${ }^{6}$, Simon Norris $^{7}$, Ken Birch ${ }^{8}$, \\ Manuel Sentis $^{9}$, José Luis García-Siñeriz ${ }^{10}$, Franz Königer ${ }^{11}$, Uwe Glaubach ${ }^{12}$, Christopher Rölke ${ }^{13}$, \\ and Ralf Diedel ${ }^{14}$ \\ ${ }^{1}$ Gesellschaft für Anlagen- und Reaktorsicherheit (GRS) gGmbH, Braunschweig, Germany \\ ${ }^{2}$ Karlsruher Institut für Technologie (KIT), \\ Kompetenzzentrum für Materialfeuchte (IMB-CMM), Karlsruhe, Germany \\ ${ }^{3}$ Bundesanstalt für Geowissenschaften und Rohstoffe (BGR), Hannover, Germany \\ ${ }^{4}$ Bundesamt für Landestopografie (swisstopo), Bern, Switzerland \\ ${ }^{5}$ TU Bergakademie Freiberg, Freiberg, Germany \\ ${ }^{6}$ Empresa nacional de residuos radiactivos (Enresa), Madrid, Spain \\ ${ }^{7}$ Radioactive Waste Management (RWM), Didcot, United Kingdom \\ ${ }^{8}$ Nuclear Waste Management Organization (NWMO), Toronto, Canada \\ ${ }^{9}$ Eidgenössisches Nuklearsicherheitsinspektorat (ENSI), Brugg, Switzerland \\ ${ }^{10}$ Amberg Infraestructuras, Alcobendas, Spain \\ ${ }^{11}$ Ingenieur-Gesellschaft für Sensorik in der Umwelttechnik mbH (ISU), Karlsruhe, Germany \\ ${ }^{12}$ Ingenieurpartnerschaft für Bergbau, Wasser und Deponietechnik (IBeWa), Freiberg, Germany \\ ${ }^{13}$ Institut für Gebirgsmechanik (IfG), Leipzig, Germany \\ ${ }^{14}$ Stephan Schmidt Gruppe, Dornburg, Germany
}

Correspondence: Klaus Wieczorek (klaus.wieczorek@grs.de)

Published: 10 November 2021

\begin{abstract}
Shaft-sealing systems for nuclear waste repositories are constructed to limit fluid inflow from the adjacent rock during the early stage after closure of the repository and to delay the release of possibly contaminated fluids from the repository at later stages. Current German concepts of shaft seals contain the hydraulic sandwich sealing system as a component of the lower seal in host rock (Kudla and Herold, 2021).

The KIT-developed sandwich sealing system consists of alternating sealing segments (DS) of bentonite and equipotential segments (ES) that are characterized by a high hydraulic conductivity. Within the ES, fluid is evenly distributed over the cross section of the seal. Water bypassing the seal via the excavation-damaged zone or penetrating the seal inhomogeneously is contained, and a more homogeneous hydration and swelling of the DS is obtained. The functionality of such a system was proven in laboratory and semi-technical-scale experiments (Schuhmann et al., 2009).

After a joint international pre-project (Emmerich et al., 2019) dedicated to the planning of a large-scale in situ test that demonstrates the feasibility and effectiveness of the sandwich shaft-sealing system in interaction with the host rock, the large-scale experiment was launched at the Mont Terri rock laboratory in July 2019 with partners from Germany, Switzerland, Spain, UK, and Canada. It consists of two experimental shafts of $1.18 \mathrm{~m}$ diameter and 10-12.6 m depth, constructed using a core drilling technique with a custom-made drill rig in a new niche in the sandy facies of the Opalinus Clay. The seal in shaft 1 consists of four DS (calcigel) of $1 \mathrm{~m}$ thickness and five ES (fine-grained quartz sand), each $30 \mathrm{~cm}$ thick (Fig. 1). Shaft sinking began in August 2020 and was completed in November 2020. In the following months, the sealing system and instrumentation of shaft 1 were installed. The sealing system is saturated from a pressure chamber located at the shaft bottom via an inclined
\end{abstract}


lateral feeding borehole. Hydration of the system started in May 2021. Shaft 2 will host a slightly modified system emplaced 1-1.5 years later, in order to integrate experience obtained during the early operation phase of shaft 1 . In contrast to shaft 1 , the excavation-damaged zone around shaft 2 will have had time to develop. The seals and the surrounding rock are intensely monitored. Measurements in the rock (geophysics, pore pressure, and total stress) were started between August 2019 and March 2020. Characterization of the excavation-damaged zone along the wall of shaft 1 was performed by geophysical and surface packer measurements prior to seal emplacement. Measurements inside the shaft comprise water content, relative humidity, and temperature, pore pressure, stress, and displacements. The in situ work is backed by laboratory testing and model simulation. Data and experience obtained to date will be presented. The sandwich experiment is funded by the German Federal Ministry for Economic Affairs and Energy under contract 02E11799.

Kurzfassung. Schachtabdichtungssysteme für nukleare Endlager werden errichtet, um in der frühen Phase nach dem Verschluss des Endlagers einen Flüssigkeitseintritt aus dem umliegenden Gestein zu begrenzen und später die Freisetzung von möglicherweise kontaminierten Flüssigkeiten aus dem Endlager zu bremsen. Zu den aktuellen Schachtabdichtungskonzepten in Deutschland gehört das hydraulische Sandwich-Verschlusssystem als Komponente der unteren Abdichtung im Wirtgestein (Kudla und Herold, 2021).

Das am KIT entwickelte Sandwich-Verschlusssystem besteht aus alternierenden Abdichtungssegmenten (DS) aus Bentonit und Äquipotentialsegmenten (ES), die sich durch eine hohe hydraulische Leitfähigkeit auszeichnen. Innerhalb der ES wird die Flüssigkeit gleichmäßig über den Querschnitt der Dichtung verteilt. Wasser, das über die Auflockerungszone um die Dichtung herumfließt oder inhomogen in die Dichtung eindringt, wird zurückgehalten, wodurch eine homogenere Hydratation und ein Quellen der DS erreicht wird. Die Funktionsfähigkeit eines solchen Systems wurde in Versuchen im Labor- und Technikumsmaßstab nachgewiesen (Schuhmann et al., 2009).

Nach einem gemeinsamen internationalen Vorprojekt (Emmerich et al., 2019) für die Planung eines großtechnischen In-situ-Tests, der die Machbarkeit und Wirksamkeit des Sandwich-Verschlusssystems im Zusammenwirken mit dem Wirtsgestein demonstriert, wurde das großtechnische Experiment im Juli 2019 im Felslabor Mont Terri mit Partnern aus Deutschland, der Schweiz, Spanien, Großbritannien und Kanada gestartet. Es besteht aus zwei Versuchsschächten mit einem Durchmesser von 1,18 m und einer Tiefe von 10-12,6 m, die im Kernbohrverfahren mit einer speziell angefertigten Bohranlage in einer neuen Nische in der sandigen Fazies des Opalinustons erstellt wurden. Die Abdichtung des Schachtes 1 besteht aus vier DS (Calcigel) mit einer Dicke von $1 \mathrm{~m}$ und fünf je $30 \mathrm{~cm}$ dicken ES (feinkörniger Quarzsand) (Abb. 1). Das Abteufen des Schachtes begann im August 2020 und wurde im November 2020 abgeschlossen. In den Monaten darauf folgten das Abdichtungssystem und die Instrumentierung von Schacht 1. Das Abdichtungssystem wird von einer Druckkammer an der Schachtsohle aus über ein geneigtes seitliches Einfüllbohrloch hydratisiert. Die Hydratation des Systems begann im Mai 2021. In Schacht 2 wird ein leicht modifiziertes System installiert, das 1-1,5 Jahre später eingebaut wird, um die Erfahrungen aus der frühen Betriebsphase von Schacht 1 zu nutzen. Im Gegensatz zu Schacht 1 wird sich die Auflockerungszone um Schacht 2 herum entwickeln können. Die Dichtungen und das umgebende Gestein werden intensiv überwacht. Messungen im Gestein (Geophysik, Porendruck und Gesamtspannung) wurden zwischen August 2019 und März 2020 begonnen. Die Charakterisierung der Auflockerungszone entlang der Wand von Schacht 1 erfolgte durch geophysikalische und Oberflächenpacker-Messungen vor dem Einbringen der Dichtungen. Die Messungen im Inneren des Schachts umfassen den Wassergehalt, die relative Feuchtigkeit und Temperatur, den Porendruck, die Spannung und die Verschiebungen. Die In-situ-Arbeiten werden durch Labortests und Modellsimulationen unterstützt. Es werden die bisher gewonnenen Daten und Erfahrungen vorgestellt. Das Sandwich-Projekt wird vom Bundesministerium für Wirtschaft und Energie im Rahmen von Vertrag 02E11799 gefördert. 


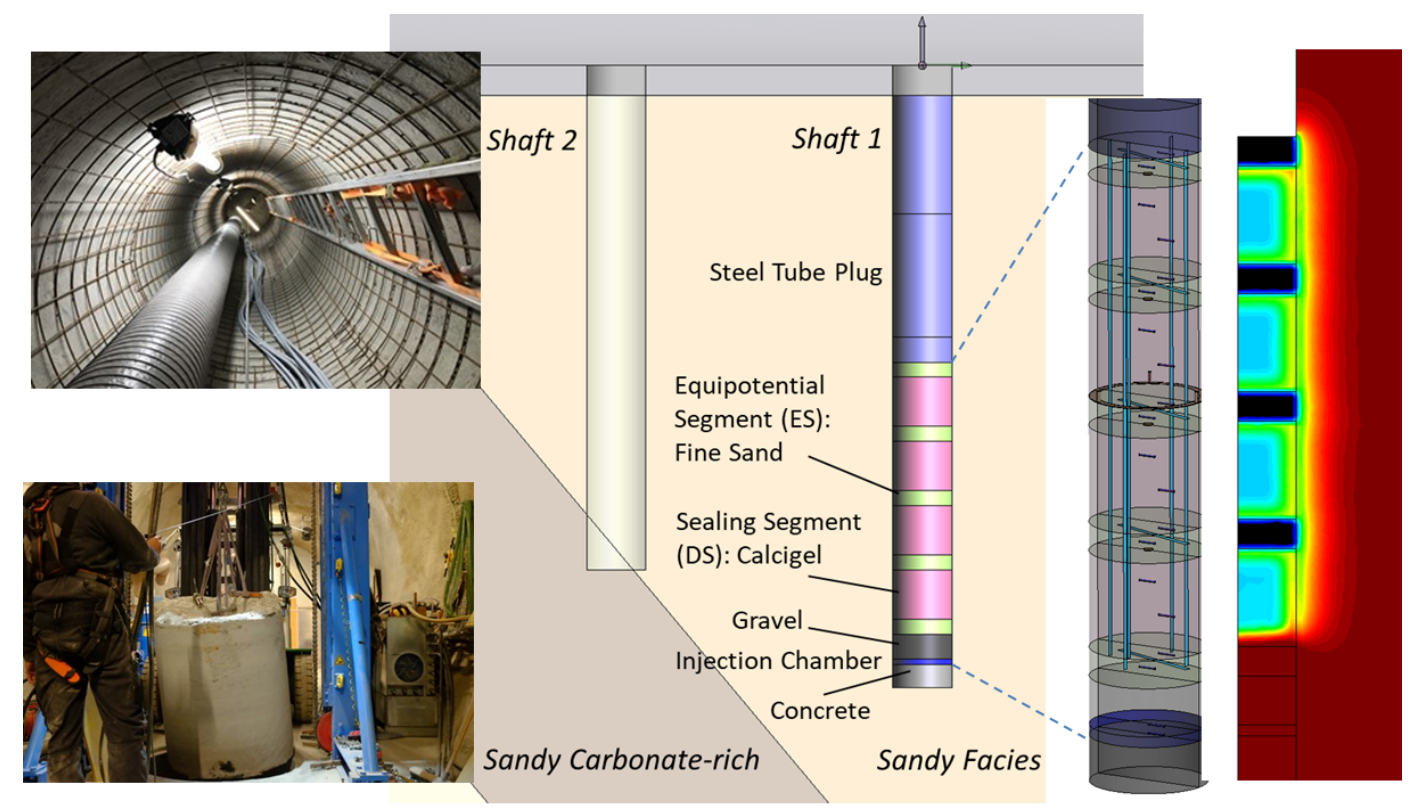

Figure 1. Sandwich large-scale experiment overview.

Financial support. This research has been supported by the Bundesministerium für Wirtschaft und Energie (grant no. 02E11799).

\section{References}

Emmerich, K., Schuhmann, R., Königer, F., Bohac, P., Delavernhe, L., Wieczorek, K., Czaikowski, O., Hesser, J., Shao, H., Jaeggi, D., Bossart, P., Hansmann, J., Gruner, M., Hofmann, M., Aurich, J., Rölke, C., Popp, T., Diedel, R., Schellhorn, M., Häußer, S., Glaubach, U., Wilsnack, T., Kemper, G., García-Siñeriz, J. L., Villar, M., Gutiérrez-Álvarez, C., and Iglesias, R. J.: Joint project: Vertical hydraulic sealing system based on the sandwich principle - preproject (Sandwich-VP), Final report, Karlsruher Institut für Technologie (KIT) \& Gesellschaft für Anlagen- und Reaktorsicherheit (GRS) gGmbH, 2019.
Kudla, W. and Herold, P.: Zusammenfassender Abschlussbericht für das Verbundvorhaben Schachtverschlüsse für Endlager für hochradioaktive Abfälle (ELSA - Phase 2): Konzeptentwicklung für Schachtverschlüsse und Test von Funktionselementen von Schachtverschlüssen, Technische Universität Bergakademie Freiberg und BGE TECHNOLOGY GmbH, 2021.

Schuhmann, R., Emmerich, K., Kemper, G., and Königer, F.: Verschlusssystem mit Äquipotenzialsegmenten für die untertägige Entsorgung (UTD und ELA) gefährlicher Abfälle zur Sicherherstellung der homogenen Befeuchtung der Dichtelemente und zur Verbesserung der Langzeitstabilität: Schlussbericht, 117 S., https://doi.org/10.2314/GBV:637752392, 2019. 